\title{
Studi Etnobotani Kelapa (Cocos nucifera) di Desa Tambi, Kecamatan Sliyeg, Kabupaten Indramayu
}

\author{
Ethnobotany Study of Coconut (Cocos nucifera) in Tambi Villages, \\ District of Sliyeg, Regency of Indramayu
}

\author{
Imah Hajjatus Solechah ${ }^{1}$, Ari Hayati ${ }^{1}$, dan Hasan Zayadi ${ }^{1 *}$ \\ Program Studi Biologi, Fakultas Matematika dan Ilmu Pengetahuan Alam, Universitas Islam Malang, \\ Malang, Indonesia
}

\begin{abstract}
Abstrak
Etnobotani adalah studi tentang hubungan antara manusia dan penggunaan tumbuhan secara tradisional. Kelapa (Cocos nucifera) merupakan salah satu tanaman yang memiliki nilai pemanfaatan yang tinggi dalam masyarakat. Berdasarkan survei awal, tanaman kelapa banyak dimanfaatkan sebagai obat, sumber pangan, bahan kerajinan dan lainnya. Penelitian ini bertujuan untuk mengetahui karakteristik, potensi, distribusi dan pemanfaatan tanaman kelapa di Desa Tambi dan Desa Tambi Lor, Kecamatan Sliyeg, Kabupaten Indramayu. Penelitian ini bermanfaat untuk memberikan informasi kepada masyarakat tentang karakteristik dan pemanfaatan tanaman kelapa serta pentingnya konservasi tanaman kelapa. Penelitian ini dilakukan dengan metode deskriptif kualitatif melalui eksplorasi pengamatan langsung di lapangan dengan wawancara menggunakan kuesioner. Hasil penelitian mendapatkan 3 varietas kelapa yang tumbuh di lokasi penelitian yaitu varietas kelapa dalam hijau, kelapa genjah kuning (gading) dan kelapa genjah hijau. Tanaman kelapa di Desa Tambi dan Desa Tambi Lor dimanfaatkan sebagai bahan pangan dan kerajinan sebesar 20\%, adat istiadat sebesar $10 \%$, obat $14 \%$, bahan bakar sebesar $16 \%$, bahan bangunan sebesar $17 \%$ dan jamu sebesar $1 \%$. Distribusi tanaman kelapa Desa Tambi ditemukan pada 18 titik, sedangkan pada Desa Tambi Lor ditemukan 22 titik tumbuh tanaman kelapa. Penyebaran tanaman kelapa berdasarkan tata guna lahan Desa Tambi hanya dijumpai pada pekarangan dan tepi sawah, sedangkan di Desa Tambi Lor, tanaman kelapa di jumpai disemua lahan yaitu pekarangan, tepi jalan, dan tepi sawah.
\end{abstract}

Kata kunci: etnobotani, tanaman kelapa, pemanfaatan, distribusi, Desa Tambi

\begin{abstract}
Ethnobotany is a study of relationship between human and traditional uses of plants. Coconut (Cocos nucifera) is one of plants that has a high utilization value in the community. Based on the initial survey, coconut plants were utilized as medicinal use, food source, handycraft and others. This study aimed determine the characteristics, potency, distribution and utilization of coconut plants in Tambi and Tambi Lor Villages, District of Sliyeg, Regency of Indramayu. The benefit of this research is to provide public information about characteristics and utilization of coconut plants and the importance of coconut plant conservation. This research was conducted using a descriptive qualitative method, namely direct exploration and observation in the field with interviews using questionnaires. There were 3 varieties of coconut found in research area, namely dalam hijau coconut, genjah kuning cococnut, and genjah hijau coconut. Coconut plants in Tambi and Tambi Lor Villages are utilized as food and handicrafts (20\%), cultural ceremony (10\%), medicine (14\%), fuel (16\%), building materials (17\%) and jamu (1\%). Coconut plants were distributed on 18 location in Tambi Village and 22 location of Tambi Lor Village. In Tambi Villages, coconut plants were mainly found on house yards and edge of rice fields. Coconut plants were widely found in all type of lands, such as house yards, roadsides, and rice fields of Tambi Lor Village.
\end{abstract}

Keywords: ethnobotany, coconut plants, utilization, distribution, Tambi villages

\footnotetext{
*Corresponding author:

Hasan Zayadi

Fakultas Matematika dan Ilmu Pengetahuan Alam, Universitas Islam Malang

Jl. MT Haryono No. 193, Malang, Indonesia, 65144

Email : hasanzayadi@unisma.ac.id
} 


\section{Pendahuluan}

Etnobotani adalah studi tentang hubungan antara manusia dan penggunaan tumbuhan secara tradisional. Dalam perkembangannya, etnobotani mempunyai ruang lingkup kajian penelitian untuk mempelajari hubungan antara manusia dan sumber daya alam di lingkungannya (Nurlina et al., 2013).

Penelitian etnobotani bisa mengkaji pemanfaatan satu atau beberapa jenis tanaman. Beberapa contoh penelitian etnobotani tentang pemanfaatan satu spesies tanaman adalah penelitian pemanfaatan tanaman Sauropus androgynus di Jawa Timur(Hayati et al., 2016), studi etnobotani Sauropus androgynus di masyarakat Pandalungan, Pasuruan (Zakiah et al., 2019), dan studi etnobotani Moringa oliefera di Sampang, Madura (Bahriyah et al., 2015).

Kelapa (Cocos nucifera) merupakan salah satu tanaman yang memiliki nilai pemanfaatan yang tinggi dalam masyarakat. Kelapa termasuk dalam marga Cocos dari suku palem-paleman atau Arecaceae. Tanaman ini diperkirakan berasal dari pesisir Samudera Hindia di sisi Asia dan kini tersebar luas di seluruh dunia. (Winarno, 2014).

Menurut Bruwadi (2005), kelapa (Cocos nucifera) merupakan salah satu hasil perkebunan strategis bagi bangsa Indonesia. Komoditas jenis ini memiliki peran penting dalam perekonomian negara, wilayah dan sosial budaya. Pada dasarnya tanaman kelapa tergolong ke dalam kelompok tanaman tahunan yang paling bermanfaat karena dapat dimanfaatkan keseluruhan bagian tubuhnya, mulai dari daun, buah, batang hingga akarnya. Oleh karena berbagai kelebihan ini, Banzon dan Velasco (1982) menamai kelapa sebagai pohon kehidupan (tree of life).

Sliyeg merupakan salah satu Kecamatan di Kabupaten Indramayu, Provinsi Jawa Barat. Secara geografis, Kecamatan Sliyeg terletak di sebelah timur Kabupaten Indramayu dan berjarak sekitar $21 \mathrm{~km}$ dari ibu kota Kabupaten Indramayu. Keadaan topografi Kecamatan Sliyeg merupakan daerah dataran rendah dengan ketinggian 7,5 meter dari permukaan laut (mdpl). Luas wilayah Kecamatan Sliyeg adalah 54,46 km² (Anonim, 2020).

Desa Tambi merupakan salah satu desa yang berada di Kecamatan Sliyeg, Kabupaten Indramayu, Provinsi Jawa Barat (Gambar 1). Desa Tambi berada di dataran rendah yaitu $8 \mathrm{mdpl}$ dengan suhu harian rata-rata berkisar antara $24^{\circ}-28^{\circ} \mathrm{C}$. Pada tahun 1986 Desa Tambi mengalami proses pemekaran menjadi dua desa yaitu Desa Tambi itu sendiri atau sering disebut dengan Desa Tambi Kidul (desa lama) dan wilayah lainnya yaitu Desa Tambi Lor (desa baru) (Wawancara Kepala Desa, 2021).

Berdasarkan hasil survei awal yang dilakukan di Desa Tambi dan Desa Tambi Lor terdapat 3 varietas tanaman kelapa yang ditemukan yaitu kelapa dalam hijau, kelapa genjah kuning dan kelapa genjah hijau. Dalam kehidupan seharihari, masyarakat Desa Tambi dan Desa Tambi Lor memanfaatkan tanaman kelapa sebagai tanaman obat, sumber pangan, bahan kerajinan dan lainnya. Penelitian ini bertujuan untuk mengetahui karakteristik, potensi, distribusi dan pemanfaatan tanaman kelapa di Desa Tambi dan Desa Tambi Lor, Kecamatan Sliyeg, Kabupaten Indramayu, Provinsi Jawa Barat.

\section{Materi dan Metode \\ Waktu dan Tempat Penelitian}

Penelitian ini dilaksanakan pada bulan Februari sampai Juli 2021 di Desa Tambi dan Desa Tambi Lor, Kecamatan Sliyeg Kabupaten Indramayu, Provinsi Jawa Barat.

\section{Alat dan Bahan}

Alat yang digunakan dalam penelitian antar lain: Global Positioning System (GPS) untuk penandaan lokasi tanaman kelapa (Cocos nucifera), kamera untuk mendokumentasi seluruh kegiatan penelitian, kuesioner untuk mendapatkan data pengetahuan masyarakat teradap potensi tanaman kelapa dan alat tulis. Bahan yang digunakan yaitu masyarakat dan seluruh tanaman kelapa (Cocos nucifera) yang berada di Desa Tambi dan Desa Tambi, Kecamatan Sliyeg, Kabupaten Indramayu, Provinsi Jawa Barat. 


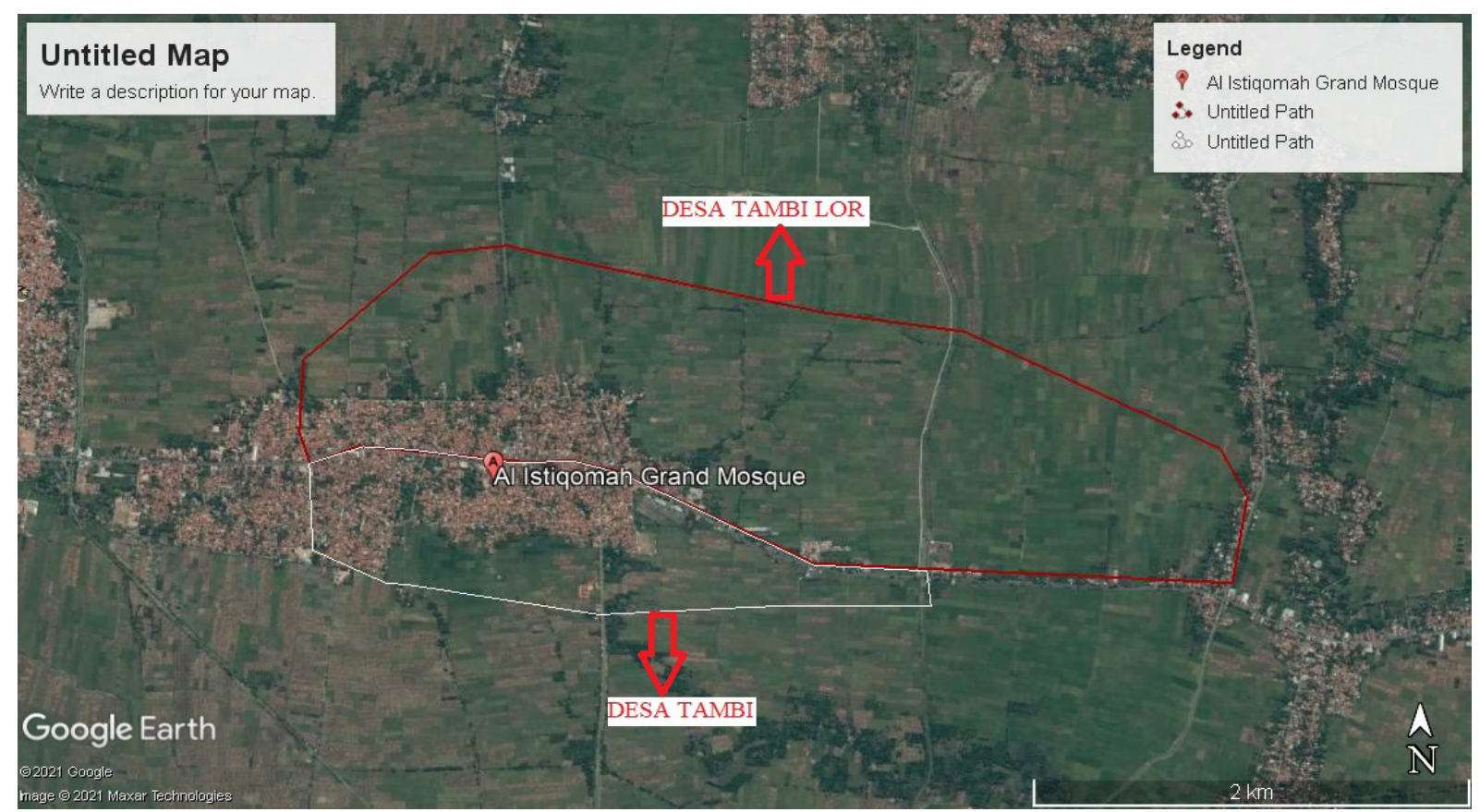

Gambar 1. Peta lokasi penelitian Desa Tambi dan Desa Tambi Lor Kecamatan Sliyeg Kabupaten Indramayu (Google Earth, 2020)

\section{Metode Penelitian}

Metode yang digunakan adalah deskriptif kualitatif yaitu melalui eksplorasi pengamatan langsung di lapangan, wawancara menggunakan kuesioner dan studi pustaka. Data yang didapatkan dari penelitian ini berupa peta umum (Google earth), keberadaan tanaman kelapa (Cocos nucifera) yang ditemukan langsung dengan survei di lokasi tempat penelitian, dan pengetahuan tentang potensi tanaman kelapa (Cocos nucifera) yang didapatkan dari wawancara dengan masyarakat. Penentuan responden mengacu pada rumus Solvin yang menghasilkan 100 responden. Total 100 responden kemudian dibagi menjadi dua populasi responden yaitu 50 responden dari Desa Tambi dan 50 responden dari Desa Tambi Lor. Pemilihan responden menggunakan teknik random sampling, dimana sampel orang diambil secara acak tanpa memperhatikan strata yang ada dalam populasi tersebut (Sugiyono, 2017) sehingga, semua masyarakat Desa Tambi dan Desa Tambi Lor memiliki kesempatan untuk dipilih menjadi responden.

\section{Hasil}

Hasil wawancara dengan Kepala Desa Tambi dan Desa Tambi Lor, Kecamatan
Sliyeg, Kabupaten Indramayu mengenai jumlah penduduk yang akan dijadikan acuan untuk menentukan jumlah responden dapat dilihat pada Tabel 1 .

Tabel 1. Responden dari Penduduk Desa Tambi

\begin{tabular}{|l|c|c|}
\hline \multicolumn{1}{|c|}{ Desa } & $\begin{array}{c}\text { Jumlah } \\
\text { Penduduk }\end{array}$ & $\begin{array}{c}\text { Jumlah Populasi } \\
\text { yang diwawancari }\end{array}$ \\
\hline Tambi & 4.511 Jiwa & 50 Jiwa \\
\hline Tambi Lor & 4.614 Jiwa & 50 Jiwa \\
\hline
\end{tabular}

Berdasarkan hasil penelitian, terdapat 3 varietas kelapa yaitu varietas kelapa dalam hijau, kelapa genjah kuning (gading) dan kelapa genjah hijau yang dijumpai di Desa Tambi dan Desa Tambi Lor Kecamatan Sliyeg Kabupaten Indramayu (Gambar 2). Hasil wawancara menggunakan kuesioner terhadap 100 responden (50 responden di Desa Tambi dan 50 responden di Desa Tambi Lor) mengenai pemanfaatan tanaman kelapa menunjukkan data besarnya pemanfaatan tanaman kelapa di Desa Tambi dan Desa Tambi Lor, Kecamatan Sliyeg, Kabupaten Indramayu. Semua bagian organ tanaman kelapa sudah dimanfaatkan oleh masyarakat Desa Tambi dan Desa Tambi Lor (Tabel 2). Persentase potensi tanaman kelapa (Cocos nucifera) oleh masyarakat Desa Tambi 


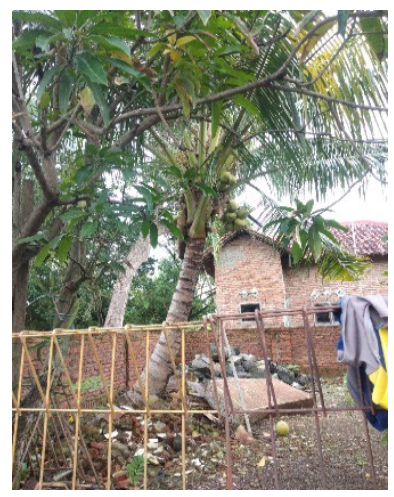

a)

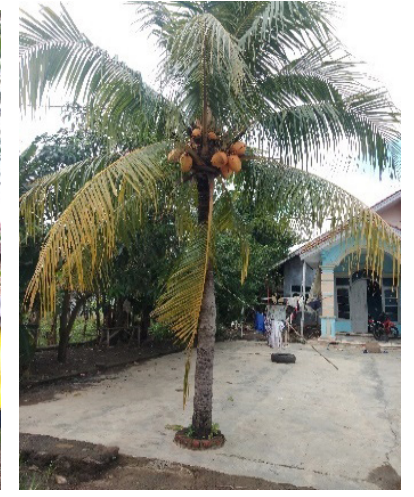

b)

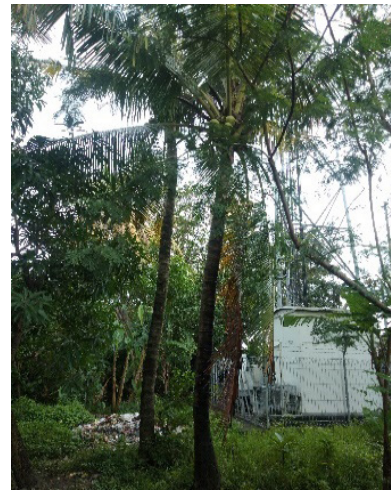

c)

Gambar 2. Varietas Kelapa a) Kelapa Dalam Hijau b) Kelapa Genjah Kuning c) Kelapa Genjah Hijau

Tabel 2. Pemanfaatan Organ tanaman kelapa (Cocos nucifera) di Desa Tambi dan Desa Tambi Lor.

\begin{tabular}{|c|c|c|c|}
\hline No & $\begin{array}{l}\text { Organ yang } \\
\text { dimanfaatkan }\end{array}$ & Pemanfaatan & Varietas kelapa \\
\hline 1 & Daun & Janur, ketupat dan atap rumah & $\begin{array}{l}\text { Kelapa dalam hijau, kelapa genjah kuning } \\
\text { (gading) dan kelapa genjah hijau }\end{array}$ \\
\hline 2 & $\begin{array}{l}\text { Anak tangkai daun } \\
\text { (lidi) }\end{array}$ & Sapu Lidi, tusuk makanan & $\begin{array}{l}\text { Kelapa dalam hijau, kelapa genjah kuning } \\
\text { (gading) dan kelapa genjah hijau }\end{array}$ \\
\hline 3 & Bunga & $\begin{array}{l}\text { Campuran gula, Kerajinan, dan Sesajen } \\
\text { (membangun rumah) }\end{array}$ & $\begin{array}{l}\text { Kelapa dalam hijau, kelapa genjah kuning } \\
\text { (gading) dan kelapa genjah hijau }\end{array}$ \\
\hline 4 & Buah & $\begin{array}{l}\text { Dijual, sesajen } 7 \text { bulanan orang hamil, } \\
\text { resepsi pernikahan dan cukur rambut } \\
\text { bayi (Aqiqah) }\end{array}$ & Kelapa dalam hijau \\
\hline 5 & Tempurung & $\begin{array}{l}\text { Bahan bakar, kerajinan alat dapur, dan } \\
\text { takaran beras }\end{array}$ & $\begin{array}{l}\text { Kelapa dalam hijau, kelapa genjah kuning } \\
\text { (gading) dan kelapa genjah hijau }\end{array}$ \\
\hline 6 & Sabut & Sapu, keset, dan penggosok panci & $\begin{array}{l}\text { Kelapa dalam hijau, kelapa genjah kuning } \\
\text { (gading) dan kelapa genjah hijau }\end{array}$ \\
\hline 7 & Daging & $\begin{array}{l}\text { Konsumsi langsung dan santan untuk } \\
\text { campuran makanan }\end{array}$ & $\begin{array}{l}\text { Kelapa dalam hijau, kelapa genjah kuning } \\
\text { (gading) dan kelapa genjah hijau }\end{array}$ \\
\hline 8 & Kentos buah & Konsumsi, Bakal bibit & $\begin{array}{l}\text { Kelapa dalam hijau, kelapa genjah kuning } \\
\text { (gading) dan kelapa genjah hijau }\end{array}$ \\
\hline 9 & Air & $\begin{array}{l}\text { Obat penawar racun, menghilangkan } \\
\text { dehidrasi, menurunkan panas, } \\
\text { kebugaran, penyubur kehamilan, dan } \\
\text { dikonsumsi langsung }\end{array}$ & Kelapa dalam hijau dan kelapa genjah hijau \\
\hline 10 & Batang & $\begin{array}{l}\text { Bahan bangunan, bahan kerajinan dan } \\
\text { bangku }\end{array}$ & $\begin{array}{l}\text { Kelapa dalam hijau, kelapa genjah kuning } \\
\text { (gading) dan kelapa genjah hijau }\end{array}$ \\
\hline 11 & $\begin{array}{l}\text { Ujung batang } \\
\text { (umbut) }\end{array}$ & Konsumsi (di sayur) & $\begin{array}{l}\text { Kelapa dalam hijau, kelapa genjah kuning } \\
\text { (gading) dan kelapa genjah hijau }\end{array}$ \\
\hline 12 & Akar & $\begin{array}{l}\text { Bahan bakar dan jamu menghilangkan } \\
\text { pegal-pegal (direbus) }\end{array}$ & $\begin{array}{l}\text { Kelapa dalam hijau, kelapa genjah kuning } \\
\text { (gading) dan kelapa genjah hijau }\end{array}$ \\
\hline
\end{tabular}

dan Desa Tambi Lor Kecamatan Sliyeg Kabupaten Indramayu disajikan dalam Gambar 3, sedangkan pemanfaatan organ tanaman kelapa oleh masyarakat Desa Tambi dan Desa Tambi Lor disajikan dalam Gambar 4.

Distribusi tanaman kelapa di Desa Tambi dan Desa Tambi Lor Kecamatan Sliyeg Kabupaten Indramayu dituliskan dalam
Gambar 5. dan keberadaan tanaman kelapa (Cocos nucifera) berdasarkan tata guna lahan yang berada di Desa Tambi dan Desa Tambi Lor Kecamatan Sliyeg Kabupaten Indramayu disajikan dalam Tabel 3.

\section{Pembahasan}

Tiga varietas kelapa yaitu kelapa dalam hijau, kelapa genjah kuning dan kelapa 


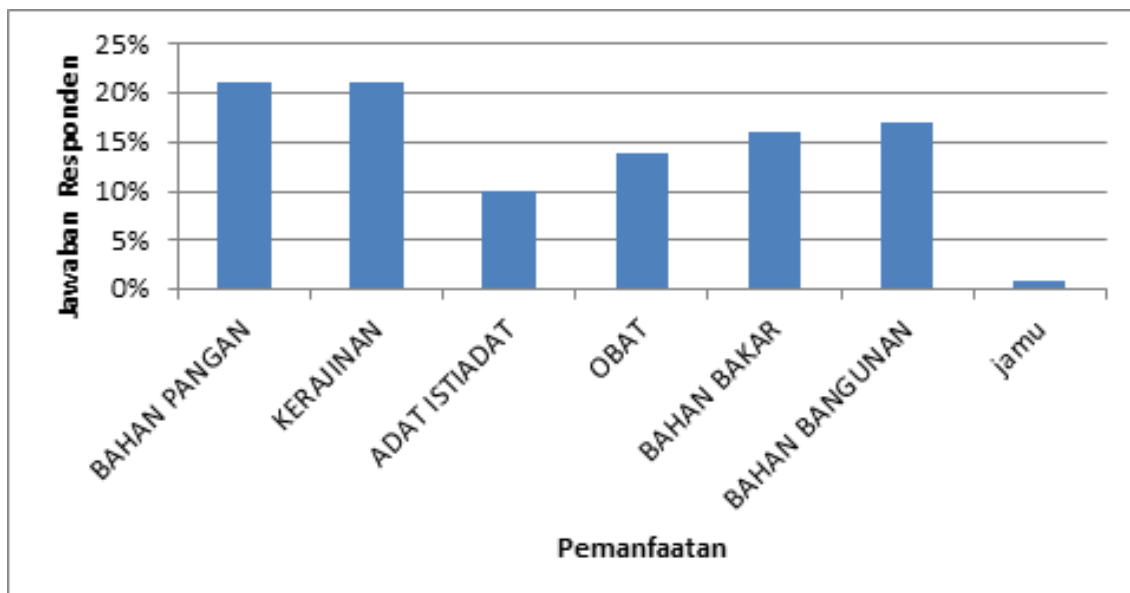

Gambar 3. Potensi Tanaman Kelapa di Desa Tambi Desa Tambi Lor
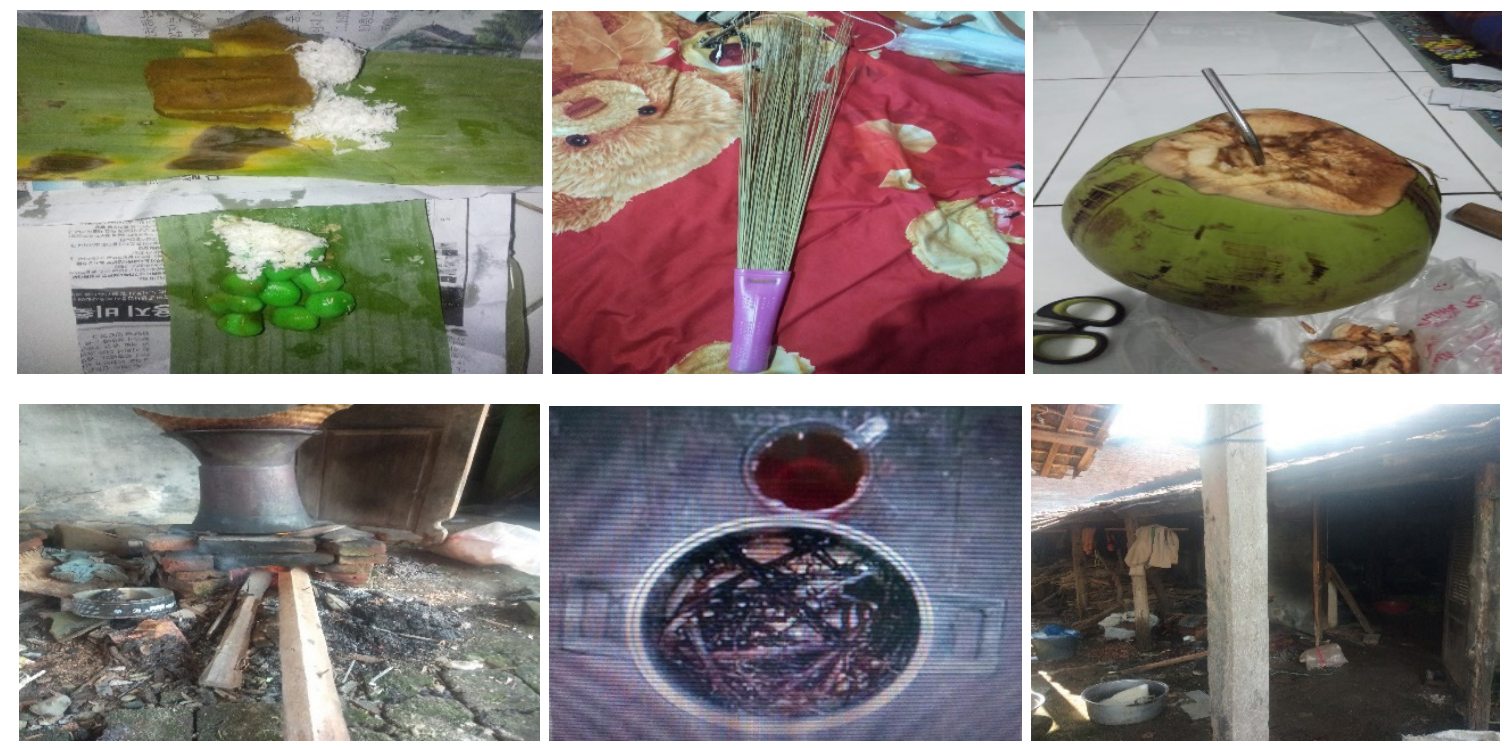

Gambar 4. Pemanfaatan Tanaman Kelapa Oleh Mayarakat Desa Tambi dan Desa Tambi Lor

genjah hijau ditemukan terdapat di Desa Tambi dan Desa Tambi Lor, Kecamatan Sliyeg, Kabupaten Indramayu. Varietas kelapa dalam hijau adalah kelapa yang memiliki kulit buah berwarna hijau. Kelapa ini tergolong kelapa dalam dengan ukuran pohon tinggi dan besar, serta buahnya berukuran besar. Varietas kelapa genjah kuning adalah kelapa yang memiliki kulit buah berwarna kuning. Kelapa ini tergolong kedalam kelapa genjah dengan habitus pohon tidak terlalu besar dan tinggi, serta buah yang dihasilkan berbentuk bulat dan berukuran kecil. Varietas kelapa genjah hijau adalah kelapa dengan kulit buah berwarna hijau, ukuran buah kecil, habitus pohon tidak terlalu tinggi dan tergolong kelapa genjah (Dalimunthe, 2014).
Masyarakat Desa Tambi dan Desa Tambi Lor memanfaatkan seluruh bagian atau organ tanaman kelapa dalam kehidupan sehari-hari (Tabel 2). Bagian atau organ daun, anak tangkai daun, bunga, tempurung, sabut, ujung batang (umbut), batang, akar, kentos buah dan daging buah dapat dimanfaatkan dari 3 varietas kelapa yang tumbuh di lokasi tersebut. Pemanfaatan hampir semua bagian tubuh tanaman kelapa juga dijumpai oleh Setia (2017) dari penelitiannya atas pemanfaatan kelapa di masyarakat Desa Sungai Itik, Provinsi Jambi. (Gunawati et al. (2018) menyatakan bahwa jenis tanaman kelapa mempunyai manfaat yang sama baik dari daun, batang, buah, tempurung dan serabut. Tenda dan Kaumanuang (2007) menyatakan bahwa bagian tanaman kelapa 


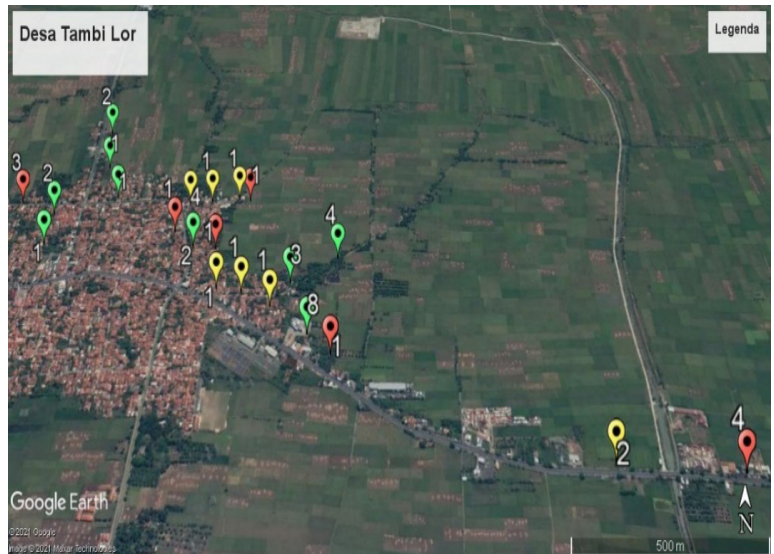

a)

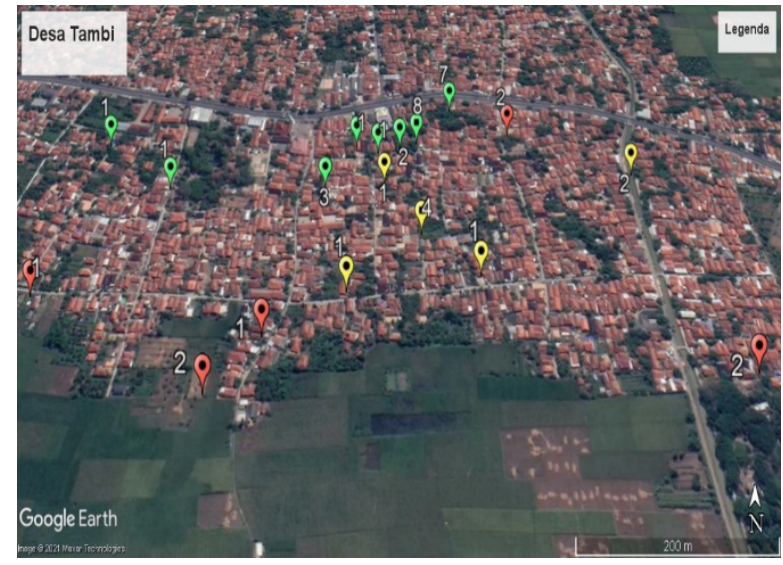

b)

Gambar 5. Peta Penyebaran Jumlah Individu Tanaman Kelapa di a) Desa Tambi b) Desa Tambi Lor

$\bullet$ : varietas kelapa dalam hijau

: varietas kelapa genjah kuning

Tabel 3. Distribusi Tanaman Kelapa (Cocos nucifera) Berdasarkan Tata Guna Lahan

\begin{tabular}{|c|c|c|c|c|}
\hline No & Desa & Pekarangan & Tepi jalan & Tepi persawahan \\
\hline 1 & Tambi & $\begin{array}{l}16 \text { titik tanaman kelapa } \\
\text { (varietas kelapa dalam hijau, } \\
\text { kelapa genjah kuning (gading) } \\
\text { dan kelapa genjah hijau) }\end{array}$ & 1, & $\begin{array}{l}\stackrel{+}{2} \text { titik tanaman kelapa (varietas } \\
\text { kelapa genjah hijau) }\end{array}$ \\
\hline 2 & Tambi Lor & $\begin{array}{l}\qquad \\
15 \text { titik tanaman kelapa } \\
\text { (varietas kelapa dalam hijau, } \\
\text { kelapa gejah kuning (gading) } \\
\text { dan kelapa genjah hijau) }\end{array}$ & $\begin{array}{l}\quad+ \\
3 \text { titik tanaman kelapa } \\
\text { (varietas kelapa genjah } \\
\text { kuning (gading)) }\end{array}$ & $\begin{array}{l}\quad+ \\
4 \text { titik tanaman kelapa (varietas } \\
\text { kelapa dalam hijau, kelapa } \\
\text { genjah kuning (gading) dan } \\
\text { kelapa genjah hijau) }\end{array}$ \\
\hline
\end{tabular}

yang paling bernilai ekonomis hingga saat ini adalah daging buahnya.

Dari hasil penelitian ini diketahui bahwa bagian daging buah kelapa dalam hijau dan kelapa genjah hijau hanya dimanfaatkan ketika daging buah masih muda, biasanya dikonsumsi langsung dengan dijadikan es degan dan campuran makanan, sedangkan daging buah kelapa genjah kuning hanya dimanfaatkan ketika daging buah sudah tua yang biasa dijadikan sebagai santan dan campuran makanan. Organ buah kelapa dalam hijau juga biasa digunakan sebagai sesajen dalam acara adat. Air kelapa varietas kelapa dalam hijau dan kelapa genjah hijau yang masih muda biasanya dimanfaatkan sebagai bahan minuman (degan) atau makanan (degan). Selain untuk tujuan konsumsi, air kelapa dalam hijau (degan) juga dapat digunakan sebagai obat. Masyarakat menggunakan air buah kelapa dalam hijau sebagai obat penawar racun, menghilangkan dehidrasi, menurunkan panas, meningkatkan kebugaran dan penyubur kehamilan.Pemanfaatan daging dan air buah kelapa selain berasal dari buah muda, juga banyak berasal dari buah tua untuk keperluan bumbu masakan

Hasil penelitian juga menunjukkan bahwa semua varietas tanaman kelapa yang ada di Desa Tambi dan Desa Tambi Lor dimanfaatkan paling besar untuk bahan pangan dan bahan kerajinan dengan masingmasing persentase sebesar 20\% (Gambar 3). Selain untuk tujuan tersebut, semua varietas tanaman kelapa yang ada juga dimanfaatkan untuk bahan bangunan (17\%), bahan bakar $(16 \%)$, keperluan adat istiadat $(10 \%)$ dan jamu (1\%). Khusus untuk varietas kelapa dalam hijau, banyak dimanfaatkan pula sebagai obat (14\%). Oleh karena semua organ tanaman kelapa bisa dimanfaatkan untuk kepentingan manusia, kelapa disebut sebagai tanaman multifungsi pendukung kehidupan (Banzon dan Velasco, 1982). 
Selain dimanfaatkan buahnya, beberapa organ atau bagian tanaman kelapa banyak dimanfaatkan untuk kebutuhan hidup masyarakat Desa Tambi dan Desa Tambi Lor. Bagian daun, anak tangkai daun, tempurung, sabut dan batang dari semua varietas kelapa yang ada biasa dijadikan sebagai bahan kerajinan dan bahan bakar (Tabel 2 dan Gambar 4). Keyakinan dan kepercayaan masyarakat terhadap adat istiadat setempat juga memanfaatkan bunga (selain buah, khusus varietas dalam hijau) dari semua varietas kelapa sebagai bahan sesajen dalam acara adat tertentu (Tabel 2 dan Gambar 4). Batang tanaman semua varietas kelapa (Cocos nucifera) yang ada di Desa Tambi dan Desa Tambi Lor banyak dimanfaatkan sebagai bahan bangunan karena sifat kayu dari batang kelapa yang kuat dan tahan lama.(Tabel 2 dan Gambar 4). Akar tanaman kelapa (Cocos nucifera) biasa dimanfaatkan sebagai jamu tradisional dengan cara direbus karena masyarakat mempercayai bahwa rebusan akar kelapa yang masih muda dapat menghilangkan pegal-pegal pada tubuh (Tabel 2 dan Gambar 4).

Data distribusi tanaman kelapa di Desa Tambi dan Desa Tambi Lor menunjukkan hasil yang tidak jauh berbeda (Gambar 5 dan Tabel 3). Hasil penelitian menunjukkan terdapatnya 18 titik tumbuh tanaman kelapa di Desa Tambi, dimana setiap titik tumbuh terkadang terdapat lebih dari satu tanaman kelapa. Tanaman kelapa yang tumbuh di Desa Tambi terdiri dari 3 varietas yaitu varietas kelapa dalam hijau, varietas kelapa genjah kuning (gading) dan varietas kelapa genjah hijau. Hasil penelitian distribusi tanaman kelapa di Desa Tambi Lor menunjukkan 22 titik tumbuh tanaman kelapa, dimana pada setiap titik tumbuh juga terkadang dijumpai lebih dari satu tanaman kelapa. Tiga varietas tanaman kelapa yang tumbuh di Desa Tambi juga dijumpai tumbuh di Desa Tambi Lor.

Data distribusi tanaman kelapa berdasarkan tata guna lahan di Desa Tambi dan Desa Tambi Lor (Tabel 3) menunjukkan adanya perbedaan. Distribusi tanaman kelapa di Desa Tambi hanya terdapat di pekarangan (15 titik tumbuh tanaman kelapa dengan varietas kelapa dalam hijau, kelapa genjang kuning, dan kelapa genjah hijau) dan tepi area persawahan (2 titik tumbuh dengan varietas kelapa gejah hijau). Persebaran tanaman kelapa di Desa Tambi Lor menunjukkan pola yang lebih merata, baik di pekarangan (15 titik tanaman kelapa dengan varietas kelapa dalam hijau, kelapa genjah kuning dan kelapa genjah hijau), tepi jalan (3 titik tanaman kelapa dengan varietas kelapa genjah kuning) dan tepi persawahan (4 titik tanaman kelapa dengan varietas kelapa dalam hijau, kelapa genjah kuning dan kelapa genjah hijau).

Relatif rendahnya jumlah titik tumbuh tanaman kelapa di Desa Tambi dan Desa Tambi Lor bisa mengindikasikan rendahnya populasi tanaman kelapa di tempat tersebut sehingga usaha perbanyakan atas tanaman kelapa perlu dilakukan. Lestarinya populasi tanaman kelapa (Cocos nucifera) di Desa Tambi dan Desa Tambi Lor, Kecamatan Sliyeg, Kabupaten Indramayu akan mendukung pemenuhan kebutuhan masyarakat setempat akan produk tanaman kelapa dalam kehidupan sehari-hari.

\section{Kesimpulan}

Tanaman kelapa yang ditemukan di Desa Tambi dan Desa Tambi Lor, Kecamatan Sliyeg, Kabupaten Indramayu terdiri dari 3 varietas yaitu kelapa dalam hijau, kelapa genjah kuning (gading) dan kelapa genjah hijau. Persentase pemanfaatan tanaman kelapa di Desa Tambi dan Desa Tambi Lor terdiri dari pemanfaatan sebagai bahan pangan dan kerajinan sebesar $20 \%$, adat istiadat sebesar $10 \%$, obat sebesar $14 \%$, bahan bakar sebesar $16 \%$, bahan bangunan sebesar $17 \%$ dan jamu sebesar $1 \%$. Distribusi tanaman kelapa pada Desa Tambi tersebar pada 18 titik tumbuh yang ditemukan di pekarangan dan tepi persawahan, sedangkan pada Desa Tambi Lor ditemukan 22 titik tumbuh tanaman kelapa yang ditemukan di pekarangan, tepi jalan dan tepi persawahan.

\section{Daftar Pustaka}

Anonim.(2020).Kecamatan Sliyeg Dalam Angka 2020. Badan Pusat Statistik Kabupaten Indramayu.

Banzon, J.A \& Velasco, J.R.(1982). Coconut: production and utilization. Philippine 
Coconut Research and Development Foundation

Bahriyah, I., Hayati, A., \& Zayadi, H. (2015). Studi Etnobotani Tanaman Kelor (Moringa oleifera) di Desa Somber Kecamatan Tambelangan Kabupaten Sampang Madura. Biosaintropis, 1(1).

Bruwadi, M. H. (2005). Peran Subsector Perkebunan Kelapa Pada Perekonomian Wilayah dan Pendapatan Rumah Tangga Petani di Provinsi Gorontalo. [Disertasi]. Universitas Padjajaran, Bandung.

Dalimunthe. M.B. (2014). Ipteks Bagi Masyarakat Kelompok Usaha Petani Kelapa Desa Sei Paham. Jurnal Pengabdian Kepada Masyarakat. Vol. 20 Nomor 77.

Gunawati, L., Kriwiyanti, E., \& Joni, M. (2018). Karakteristik Dan Analisis Kekerabatan Ragam Kelapa (Cocos nucifera L.) Di Kabupaten Manggarai Barat Berdasarkan Karakter Morfologi Dan Anatomi. Jurnal Simbiosis VI (1): 20-24 ISSN: 2337-7224

Hayati, A., Arumingtyas, E. L., Indriyani, S., \& Hakim, L. (2016). Local Knowledge of Katuk (Sauropus androgynus L. Merr) in East Java, Indonesia. International Journal of Current Pharmaceutical Review and Research, 7(4), 210-215.

Nurlina, R., H. A. Hidayah. M., \& Y. Widiawati. (2013). Kajian Etnobotani Masyarakat Adat Kampung Pulo di Kabupaten Garut Purwokerto. Universitas Jendral Sudirman.

Setia, N. (2017). Etnobotani Kelapa (Cocos nucifera) pada Masyarakat Desa Sungai Itik Kecamatan Sadu Kabuoaten Tanjung Jabung Timur. Skripsi. Fakultas Keguruan dan Ilmu Pendidikan Universitas Jambi.

Sugiyono. (2017). Metode Penelitian Pendidikan Pendekatan Kuantitaif, Kualitatif dan R\&D. Bandung: Alfabeta $\mathrm{CV}$

Tenda, E.T \& Kaumanuang, J. (2007). Keragaman fenotipik kelapa dalam di Kabupaten Pacitan, Tulungagung dan Lumajang Jawa Timur. Buletin Palma $32,22-29$.
Winarno, F. G. (2014). Kelapa Pohon Kehidupan. Jakarta: PT Gramedia Pustaka Utama.

Zakiah, E., Hayati, A., \& Zayadi, H. (2019). Etnobotani Aspek Pemanfaatan an Konservasi Katuk (Sauropus androgynus L. Merr.) pada Masyarakat Pandalungan Kecamatan Prigen Kabupaten Pasurua dan Konservasi Katuk (Sauropus androgynus L. Merr.) pada Masyarakat Pandalungan Kecamatan Prigen Kabupaten Pasuruan. Biosaintropis, 4, 8-14. 